\title{
Impact of Organic Mulches and Intercropping on Microbial Population and Enzyme Activities in Irrigated Finger Millet (Eleusine coracana L.)
}

\author{
R. Vishalini ${ }^{1 *}$, D. Rajakumar ${ }^{1}$ and M. Gomathy ${ }^{2}$ \\ ${ }^{1}$ Department of Agronomy, ${ }^{2}$ Department of SS \& AC, Agricultural College and Research \\ Institute, Killikulam Vallanadu 628 252, Tamil Nadu, India \\ *Corresponding author
}

\section{Keywords}

Finger millet, Soil microbial population, Soil biomass carbon, Soil enzymatic activity

Article Info

Accepted: 04 May 2019 Available Online: 10 June 2019

\section{A B S T R A C T}

Field experiment was conducted at the Department of Agronomy, Agricultural college and Research Institute, Killikulam, to study the impact of organic mulches and intercropping on microbial population and enzyme activity in irrigated Finger millet in a factorial randomized block design (FRBD). The treatments consisted of mulching as main factor including rice straw, coconut shredded waste and a control without mulch. The sub factor included intercrops black gram, small onion, palak, coriander and a control without intercrops. Rhizospheric soil samples were collected on 60 DAS and were analyzed for microbial population, biomass carbon and dehydrogenase activity. Application of rice straw mulch without intercrop $\left(\mathrm{M}_{1} \mathrm{I}_{0}\right)$ recorded significantly higher population of bacteria, fungi, actinobacteria $\left(41.3 \times 10^{7}, 33.0 \times 10^{5}\right.$ and $17.3 \times 10^{3} \mathrm{CFU} \mathrm{g}{ }^{-1}$ soil respectively), soil biomass carbon $\left(0.456 \mathrm{~g}\right.$ of $\mathrm{CO}_{2} / 10 \mathrm{~g}$ of soil) and higher activity of dehydrogenase (1.534 $\mu \mathrm{g}$ of TPF $\mathrm{g}^{-1}$ of dry soil $\mathrm{h}^{-1}$ ) followed by coconut shredded waste mulching without intercrops $\left(\mathrm{M}_{2} \mathrm{I}_{0}\right)$.

\section{Introduction}

Finger millet is an important cereal crop of subsistence agriculture that offers enormous advantages such as early maturity, wider adaptability, low input cost and high nutritious value of grain. It is grown on an area of 10.16 lakh hectare in India with a total production of 1385 lakh tonnes and productivity of $1363 \mathrm{~kg} \mathrm{ha}^{-1}$ (Ministry of Agriculture \& Farmers Welfare, Govt. of India, 2017). The production and productivity of finger millet is low which is mainly attributed to inefficient nutrient management and heavy weed infestation. In the recent years, there has been reduction in the usage of organic manures and increase in the use of inorganic fertilizers to obtain higher yields from hybrids and improved varieties. But as alternate crop residues such as mulch can increase the productivity of soils as they act as a source of nutrients and modify the soil physical behavior as well as increase the efficiency of applied nutrients in an agroecosystem (Sahadeva Reddy and Aruna, 2008). Intercropping was also proved to 
suppress the weeds by minimizing the space available to them and utilizing the resources which were being depleted by weeds previously (Farooq et al., 2011).

The enzyme activity in soil is considered as an index of microbial activity, which is influenced by nature, age of crop and addition of fertilizers and manures. Intensive use of fertilizers, nutrients, manures and other soil amendments used to maximize production may thus affect soil properties. Microbial enzymes have essential functions in the soil and have been used to measure the influence of soil management and quality (Riffaldi et al., 2003). The activities of microorganisms play a pivotal role in nutrient recycling, organic matter and decomposition as they provide living environment to the soil and perform key role in transformation of nutrients to available forms, decomposition of organic residues, biochemical activities and enzymatic activities. Soil enzymes and their activity is considered as an indicator of soil fertility' and 'sensors' of soil degradation since they integrate information about microbial status and physico-chemical conditions of soil in relation to nutrient availability (Aon and Colaneri, 2001).

Application of plant residues into soil have beneficial effects on a number of soil properties such as, structure, organic matter content, water capacity, lowered soil temperature and moisture fluctuation. Though, the importance of microflora for residue decomposition and mineralization has already been recognized, but little is known about changes in microbial and enzyme activities during the period of decomposition. Many of the researchers have concentrated on the effect of different kinds of mulches and fertilizers on plants and soil temperature, water and nutrient content (Shen et al., 2016) but the influence of crop residues as mulches on the finger millet rhizosphere remains unanswered and poorly understood. Exploring the microbial activities in the rhizophere of finger millet is need of the hour for sustaining the soil health, quality and essential for intensive millet production for meeting the demands of nutri cereals.

By keeping all the above points in view, the present study was undertaken with an objective to know the effect of organic mulches and intercropping on microbial population, enzyme activity and yield in irrigated finger millet.

\section{Materials and Methods}

Field experiment was conducted at the ' $\mathrm{B}$ ' block of Department of Agronomy, Agricultural College and Research Institute, Killikulam during rabi season of 2018-2019. The soil of the experimental field was sandy loam in nature and $\mathrm{pH}, \mathrm{EC}$, available nitrogen, phosphorus and potassium were determined using standard analytical procedures. The experiment was laid out in Factorial Randomized Block design (FRBD) and replicated thrice. Main factor consisted of rice straw mulching $\left(\mathrm{M}_{1}\right)$, coconut shredded waste mulching $\left(\mathrm{M}_{2}\right)$ and without mulch $\left(\mathrm{M}_{0}\right)$ as control whereas sub factor included four intercropping $\left(\left(\mathrm{I}_{1}\right)\right.$ blackgram, $\left(\mathrm{I}_{2}\right)$ coriander, $\left(\mathrm{I}_{3}\right)$ small onion and (I4) palak) treatments and a control $\left(\mathrm{I}_{0}\right)$. The rhizosphere soil samples were collected from respective plots at 60 days after sowing (DAS).

\section{Enumeration of soil microbial population}

Soil microbial population was enumerated from soil samples collected at 60 DAS of crop. The rhizosphere soil samples collected from experimental field were analyzed for soil microorganisms viz., total bacteria, fungi and actinobacteria using serial dilution and plating technique. The media used were Nutrient agar, Martin's Rose Bengal agar and 
Kenknight's agar for bacteria, fungi and actinobacteria respectively. The number of colonies were counted and multiplied by the dilution factor for the concerned group of microorganisms and expressed as number of colony forming units (CFU) per gram of oven dry soil.

\section{Soil dehydrogenase activity}

Dehydrogenase activity was enumerated from soil samples collected at 60 DAS. The pre incubated soil sample $(2 \mathrm{~g})$ was added with 1 $\mathrm{ml}$ of 2, 3, 5- tri-phenyl Formazon (3\%) and $2.5 \mathrm{ml}$ of distilled water to create anaerobic conditions. Samples were mixed thoroughly with glass rod and incubated at $37^{\circ} \mathrm{C}$ for 24 hours. The soil solution was filtered through cotton plug at the tip of the funnel and washed with methanol and diluted to $100 \mathrm{ml}$. The red color intensity was measured at $485 \mathrm{\eta m}$ (Casida et al., 1964) by taking methanol as blank.

\section{Soil Biomass Carbon}

Biomass carbon in soil was determined by Fumigation and Incubation method (Jenkinson, 1966). The incubated soil samples $(10 \mathrm{~g})$ received $2 \mathrm{ml}$ of ethanol free chloroform and sealed with wax paper to ensure elimination of interference of atmospheric $\mathrm{CO}_{2}$.

In a scintillation vial $5 \mathrm{ml}$ of $0.5 \mathrm{~N}$ sodium hydroxide was tied in both fumigated and non-fumigated samples to trap the evolved $\mathrm{CO}_{2}$. Added $50 \%$ barium chloride solution was added to precipitate the $\mathrm{CO}_{2}$ trapped in sodium hydroxide. Few drops of phenolphthalein indicator was added and titrated against $0.5 \mathrm{~N}$ Hydrochloric acid to quantify the $\mathrm{CO}_{2}$ trapped in the solution. Correction factor of 0.54 was used to get the biomass carbon value at 60 DAS of the crop.

\section{Results and Discussion}

The soil of the experimental field was neutral in reaction ( $\mathrm{pH}$ of 7.04$)$, low in available nitrogen $242 \mathrm{~kg} / \mathrm{ha}$, medium in available phosphorus $21 \mathrm{~kg} / \mathrm{ha}$ and medium in available potassium $236 \mathrm{~kg} / \mathrm{ha}$. The results obtained in the experiment are discussed hereunder.

\section{Microbial population}

Both organic mulching alone or in combination with intercropping showed significant effect on microbial population. The maximum bacterial, fungal and actinobacterial population was noticed during 60 DAS in the rice straw mulching without intercrop $\left(\mathrm{M}_{1} \mathrm{I}_{0}\right)\left(41.3 \times 10^{7}, 33.0 \times 10^{5}\right.$ and $17.3 \times 10^{3} \mathrm{CFU} \mathrm{g}^{-1}$ soil) followed by coconut shredded waste mulch without intercrops $\left(\mathrm{M}_{2} \mathrm{I}_{0}\right)\left(33.7 \times 10^{7}, 31.0 \times 10^{5}\right.$ and $15.3 \times 10^{3}$ CFU $\mathrm{g}^{-1}$ soil) and the lowest population was recorded in the treatment without mulch and black gram as intercrop $\left(\mathrm{M}_{0} \mathrm{I}_{1}\right)\left(11.3 \times 10^{5}\right.$, $12.3 \times 10^{6}$ and $5.0 \times 10^{2}$ CFU g ${ }^{-1}$ soil), respectively (Table 1). The increase in microbial population with the incorporation of organics mulches (rice straw and coconut shredded waste) might be due to the supply of large amount of carbon, a major food source for several bacteria, fungi and actinobacteria involved in decomposition.

\section{Microbial biomass carbon content ( $\mathrm{g}$ of $\mathrm{CO}_{2} / 10 \mathrm{~g}$ of soil)}

In the present investigation, microbial biomass $\mathrm{C}$ content in soil was found to be relatively higher in the treatments amended with organic mulches, irrespective of the intercrops grown. Significantly, higher microbial biomass carbon was obtained in the treatment with rice straw mulching alone (0.456 $\mathrm{g}$ of $\mathrm{CO}_{2} / 10 \mathrm{~g}$ of soil) followed by coconut shredded waste mulch $(0.434 \mathrm{~g}$ of $\mathrm{CO}_{2} / 10 \mathrm{~g}$ of soil) (Table 1). In the treatments 
without mulches and with intercrops lower biomass carbon was recorded which ranged from 0.206 to $0.400 \mathrm{~g}$ of $\mathrm{CO}_{2} / 10 \mathrm{~g}$ of soil at 60 DAS (Fig. 1). The present results were in line with $\mathrm{Tu}$ et al., (2006) who showed that microbial biomass was high in soil under straw mulch conditions in relation to nonmulched soil. Organic mulches besides being a good source of carbon and nutrients is also responsible for increasing the organic matter content of the soil.

This could be one of the important reasons for relatively higher microbial biomass $\mathrm{C}$ content in the soil. The results were similar to the research work of Van Groenigen et al., (2010) who reported that the flow of carbon (C) through ecosystems from agricultural management was largely mediated by the population of microorganisms in the soil. Amount of organic matter incorporated into the soil directly influence the soil enzymatic activity and microbial biomass (Saha et al., 2008).

\section{Enzyme activity}

\section{Dehydrogenase activity ( $\mu$ TPF / g soil)}

Dehydrogenase activity is an indicator of overall soil microbial activity and reflects the total scope of activity of soil microflora (Nannipieri et al., 2003) and serve as an early and sensitive indicator of soil ecosystem health (Oliveira and Pampulha, 2006). Similar trend as of soil microbical biomass carbon was observed in dehydrogenase actiity, though there was significant among the treatments at 60 DAS. Rice straw and coconut shredded waste mulches without intercrops recorded 1.534 and $1.418 \mu \mathrm{g}$ of TPF $\mathrm{g}^{-1}$ of dry soil $\mathrm{h}^{-1}$ respectively (Table 2). Among the intercrops without mulching, the lowest enzyme activity was observed in blackgram intercropping $\left(\mathrm{M}_{0} \mathrm{I}_{1}\right)\left(0.726 \mu \mathrm{g}\right.$ of TPF $\mathrm{g}^{-1}$ of dry soil $\mathrm{h}^{-1}$ ) of dehydrogenase. Mulching enhanced the soil enzymatic activity compared to unmulching that might be due to the availability of moisture in the mulched soil due to lesser evaporation of water. Similar results were observed by Siczek and Frac (2012) who found higher enzymatic activity in the mulched soil of soybean.

In our study mulch application enhanced soil enzymes activity as compared to unmulched soil. This could partially results from improvement of water availability by mulching through reducing evaporation

The soil dehydrogenase activity increased with addition of organic carbon through organic mulches with different intercrops. The activity of enzymes can be attributed to microbial origin developed during decomposition of organic sources of nutrients. Addition of organic mulches acts as a good source of carbon and energy to heterotrophs by which their population increased with an increase in enzymatic activities (Hebbal et al., 2018).

\section{Effect of organic mulches and intercropping on grain yield in irrigated finger millet}

Application of organic mulches and intercropping exerted significant influence on the grain yield. Higher grain yield of 4400 $\mathrm{kgha}^{-1}$ was recorded in the treatment receiving rice straw mulch $\left(\mathrm{M}_{1} \mathrm{I}_{0}\right)$ alone without intercropping (Fig. 1).

Higher grain yield can be attributed to the ability of microorganisms to decompose and mineralize the organic mulches and other soil nutrients in the soil and made available to the crop to satisfy the nutrient demand of crop more efficiently. The type and quality of the mulch decides the available nutrients and organic carbon content of the soil. 
Table.1 Effect of organic mulches and intercropping on bacteria, fungi and actionbacteria (CFU per gram of soil) population at 60 DAS in irrigated Finger millet

\begin{tabular}{|c|c|c|c|c|c|c|c|c|c|}
\hline \multirow{2}{*}{$\begin{array}{c}\text { Treatments/ } \\
\text { Day of } \\
\text { observation }\end{array}$} & \multicolumn{3}{|c|}{ Bacteria (CFU per gram of soil) } & \multicolumn{3}{|c|}{ Fungi (CFU per gram of soil) } & \multicolumn{3}{|c|}{ Actinobacteria (CFU per gram of soil) } \\
\hline & $\mathbf{M}_{\mathbf{0}}$ & $\mathbf{M}_{1}$ & $\mathbf{M}_{2}$ & $\mathbf{M}_{\mathbf{0}}$ & $\mathbf{M}_{1}$ & $\mathbf{M}_{2}$ & $\mathbf{M}_{\mathbf{0}}$ & $\mathbf{M}_{1}$ & $\mathbf{M}_{2}$ \\
\hline $\mathbf{I}_{\mathbf{0}}$ & $\begin{array}{c}33.7 \times 10^{7} \\
(1.52)\end{array}$ & $\begin{array}{c}41.3 \times 10^{7} \\
(1.61)\end{array}$ & $\begin{array}{c}33.7 \times 10^{7} \\
(1.52)\end{array}$ & $\begin{array}{c}28.3 \times 10^{5} \\
(1.45)\end{array}$ & $\begin{array}{c}33.0 \times 10^{5} \\
(1.51)\end{array}$ & $\begin{array}{c}31.0 \times 10^{5} \\
(1.49)\end{array}$ & $\begin{array}{c}15.0 \times 10^{3} \\
(1.17)\end{array}$ & $\begin{array}{c}17.3 \times 10^{3} \\
(1.24)\end{array}$ & $\begin{array}{c}15.3 \times 10^{3} \\
(1.18)\end{array}$ \\
\hline $\mathbf{I}_{\mathbf{1}}$ & $\begin{array}{c}11.3 \times 10^{5} \\
(1.05)\end{array}$ & $\begin{array}{c}30.3 \times 10^{6} \\
(1.48)\end{array}$ & $\begin{array}{c}16.7 \times 10^{6} \\
(1.22)\end{array}$ & $\begin{array}{c}12.3 \times 10^{6} \\
(1.09)\end{array}$ & $\begin{array}{c}27.0 \times 10^{5} \\
(1.43)\end{array}$ & $\begin{array}{c}19.7 \times 10^{4} \\
(1.29)\end{array}$ & $\begin{array}{c}5.0 \times 10^{2} \\
(0.63)\end{array}$ & $\begin{array}{c}14.3 \times 10^{3} \\
(1.15)\end{array}$ & $\begin{array}{c}9.7 \times 10^{5} \\
(0.98)\end{array}$ \\
\hline $\mathbf{I}_{2}$ & $\begin{array}{c}12.0 \times 10^{4} \\
(1.08)\end{array}$ & $\begin{array}{c}20.3 \times 10^{6} \\
(1.30)\end{array}$ & $\begin{array}{c}12.7 \times 10^{6} \\
(1.09)\end{array}$ & $\begin{array}{c}14.0 \times 10^{3} \\
(1.14)\end{array}$ & $\begin{array}{c}20.3 \times 10^{5} \\
(1.31)\end{array}$ & $\begin{array}{c}16.3 \times 10^{4} \\
(1.21)\end{array}$ & $\begin{array}{c}6.7 \times 10^{2} \\
(0.80)\end{array}$ & $\begin{array}{c}10.3 \times 10^{2} \\
(1.01)\end{array}$ & $\begin{array}{c}7.7 \times 10^{2} \\
(0.88)\end{array}$ \\
\hline $\mathbf{I}_{3}$ & $\begin{array}{c}14.7 \times 10^{4} \\
(1.16)\end{array}$ & $\begin{array}{c}29.7 \times 10^{6} \\
(1.46)\end{array}$ & $\begin{array}{c}28.3 \times 10^{5} \\
(1.45)\end{array}$ & $\begin{array}{c}19.0 \times 10^{3} \\
(1.28)\end{array}$ & $\begin{array}{c}24.3 \times 10^{5} \\
(1.38)\end{array}$ & $\begin{array}{c}24.0 \times 10^{5} \\
(1.38)\end{array}$ & $\begin{array}{c}8.7 \times 10^{2} \\
(0.93)\end{array}$ & $\begin{array}{c}14.0 \times 10^{2} \\
(1.14)\end{array}$ & $\begin{array}{c}12.3 \times 10^{2} \\
(1.09)\end{array}$ \\
\hline $\mathbf{I}_{4}$ & $\begin{array}{c}13.0 \times 10^{4} \\
(1.11)\end{array}$ & $\begin{array}{c}21.3 \times 10^{5} \\
(1.32)\end{array}$ & $\begin{array}{c}22.3 \times 10^{5} \\
(1.35)\end{array}$ & $\begin{array}{c}17.7 \times 10^{3} \\
(1.24)\end{array}$ & $\begin{array}{c}21.7 \times 10^{5} \\
(1.33)\end{array}$ & $\begin{array}{c}23.3 \times 10^{5} \\
(1.37)\end{array}$ & $\begin{array}{c}8.0 \times 10^{2} \\
(0.88)\end{array}$ & $\begin{array}{c}10.7 \times 10^{2} \\
(1.02)\end{array}$ & $\begin{array}{c}11.3 \times 10^{2} \\
(1.05)\end{array}$ \\
\hline & & SEd & CD (0.05) & & SEd & CD (0.05) & & SEd & CD (0.05) \\
\hline & $\mathbf{M}$ & 0.027 & 0.055 & & 0.025 & 0.052 & & 0.043 & 0.087 \\
\hline & $\mathbf{I}$ & 0.035 & 0.072 & & 0.032 & 0.067 & & 0.055 & 0.113 \\
\hline & M x I & 0.061 & 0.124 & & 0.057 & NS & & 0.096 & NS \\
\hline
\end{tabular}

*(values in the parenthesis are log transformed) 
Table.2 Effect of Organic mulches and intercropping on soil microbial biomass carbon ( $\mathrm{g}$ of $\mathrm{CO}_{2} / 10 \mathrm{~g}$ of soil) and dehydrogenase enzyme activity ( $\mu \mathrm{g}$ of TPF $\mathrm{g}^{-1}$ of dry soil $\mathrm{h}^{-1}$ ) at 60 DAS in irrigated Finger millet

\begin{tabular}{|c|c|c|c|c|c|c|}
\hline \multirow{2}{*}{$\begin{array}{l}\text { Treatments } \\
\text { / Day of } \\
\text { observation }\end{array}$} & \multicolumn{3}{|c|}{$\begin{array}{l}\text { Soil microbial biomass carbon } \\
\text { ( } \mathrm{g} \text { of } \mathrm{CO}_{2} / 10 \mathrm{~g} \text { of soil) }\end{array}$} & \multicolumn{3}{|c|}{$\begin{array}{l}\text { Dehydrogenase enzyme activity } \\
\left(\mu \mathrm{g} \text { of TPF } \mathrm{g}^{-1} \text { of dry soil } \mathbf{h}^{-1}\right)\end{array}$} \\
\hline & $\mathbf{M}_{0}$ & $\mathbf{M}_{1}$ & $\mathbf{M}_{2}$ & $\mathbf{M}_{0}$ & $\mathbf{M}_{1}$ & $\mathbf{M}_{2}$ \\
\hline $\mathbf{I}_{0}$ & 0.400 & 0.456 & 0.434 & 1.414 & 1.534 & 1.418 \\
\hline $\mathbf{I}_{1}$ & 0.206 & 0.404 & 0.327 & 0.726 & 1.312 & 0.944 \\
\hline $\mathbf{I}_{2}$ & 0.230 & 0.331 & 0.258 & 0.742 & 0.998 & 0.751 \\
\hline $\mathbf{I}_{3}$ & 0.316 & 0.393 & 0.378 & 0.913 & 1.308 & 1.216 \\
\hline \multirow[t]{5}{*}{$\mathbf{I}_{4}$} & 0.315 & 0.344 & 0.359 & 0.850 & 1.129 & 1.169 \\
\hline & & SEd & CD (0.05) & & SEd & CD (0.05) \\
\hline & M & 0.022 & 0.046 & & 0.016 & 0.034 \\
\hline & I & 0.029 & 0.060 & & 0.021 & 0.043 \\
\hline & M X I & 0.051 & NS & & 0.037 & 0.076 \\
\hline
\end{tabular}

Fig.1 Effect of organic mulches and intercropping on yield $\left(\mathrm{kg} \mathrm{ha}^{-1}\right)$ in irrigated Finger millet

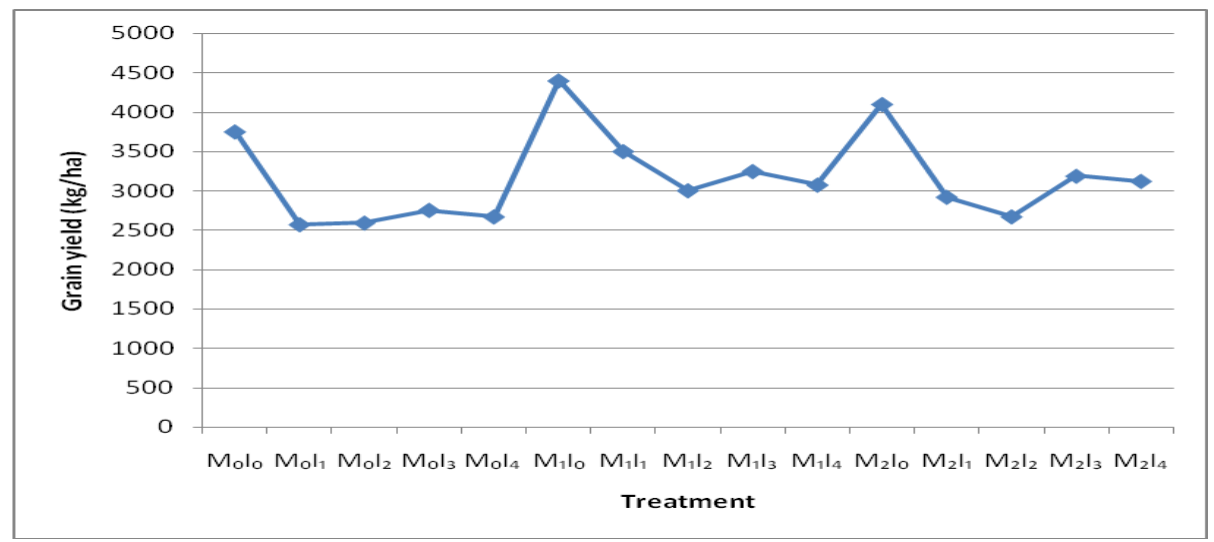

Buck et al., (2000) concluded that quality of the mulch is vital and have much influence on soil biological properties that helped the plants to attain increased yield. Siczek and Lipiec (2011) observed that soil enzyme activity was higher due to the application of straw mulch which showed greater yield in soybean compared to unmulched soil.

From this study, it can be concluded that rice straw mulch without intercrop in irrigated finger millet influenced the rhizospheric soil by increasing the microbial community by enhancing the availability of nutrients and activity of soil enzymes and hence can be recommended for obtaining higher grain yield in irrigated finger millet. The use of chemical fertilizers, can be minimized or replaced by the use of locally available crop residues especially paddy straw as mulch to attain better yield in smart nutri cereals to achieve millet mission in 2019.

\section{References}

Aon, M.A. and Colaneri, A.C. 2001. Temporal and special evaluation of enzymatic activities and physicochemical properties in agricultural soil. Applied Soil 
Ecology. 18: 255 - 270.

Buck C., Langmaack M. and Schrader, S. 2000. Influence of mulch and soil compaction on earthworm cast properties. Appl. Soil Ecol., 14: 223 229.

Casida, L., Klein, D. and Santoro, T. 1964. Soil Dehydrogenase Activity. Soil Science, 98, pp. 371-376

Farooq, M., Siddique, K. H. M., Rehman, H. U., Aziz, T., Lee, D. J., Wahid, A. 2011. Rice direct seeding: Experiences, challenges and opportunities. Soil Till Res., 111: 8798.

Jenkinson, D. S. 1966. Studies on the decomposition of plant material in soil. II. Partial sterilization of soil and the soil biomass. J. Soil Sci. 17: 280302.

Nannipieri P, Ascher J, Ceccherini MT, Landi L, Pietramellara G, Renella G (2003) Microbial

diversity and soil functions. Eur J Soil Sci 54:655-670

Nannipieri, P., Ascher, J., Ceccherini, M.T., Landi, L., Pietramellara, G., Renella, G. 2003. Microbial diversity and soil function. Eur. J. Soil. 54: 655-670.

Hebbal, R., B. K. Ramachandrappa, M. N. Thimmegouda, Mudalagiriyappa and Brahmaprakash, G.P. 2018. Soil microbial population and soil enzymatic activity in Finger Millet as influenced by effect of planting geometry, methods of establishment and nutrient. Int. J. Curr. Microbiol. App. Sci. 7 (03): 2096-2102.

Oliveira, A. and M.E. Pampulha. 2006. Effects of long-term heavy metal contamination on soil microbial characteristics. J. Biosci. Engin. 102:157-161.

Sahadeva Reddy, B. and Aruna, E. 2008. Integrated nutrient management in hybrid sorghum. J. Cotton Res. and
Dev. 22 (2): 153- 156

Saha, S., Prakash, V., Kundu, S., Kumar, N. and Mina, B.L. 2008. Soil enzymatic activity as affected by long term application of farm yard manure and mineral fertilizer under a rainfed soybean-wheat system in NW Himalaya. Eur. J. Soil Biol., 44: 309315.

Shen, Y, Yingying Chen and Shiqing Li. 2016. Microbial functional diversity, biomass and activity as affected by soil surface mulching in a semiarid farmland. PLoS ONE 11 (7): 0159144.

Siczek, A. and Lipiec, J. 2011. Soybean nodulation and nitrogen fixation in response to soil compaction and surface straw mulching. Soil Till. Res., 114: 50-56.

Siczek, A. and Frac, M. 2012. Soil microbial activity as influenced by compaction and straw mulching. International Agrophysics. 26 (1): 65-69.

Riffaldi, R., A. Saviozzi, R. Levi-Minzi, and R. Cardelli. 2003. Conventional crop management effects on soil organic matter characteristics. Agronomie 23:45-50

Riffaldi, R., Saviozzi, A., Levi-Minzi, R. and Cardelli, R. 2003. Conventional crop management effects on soil organic matter characteristics. Agronomie. 23: 45-50.

Tu, C., Ristaino, J.B., and Hu, S. 2006. Soil microbial biomass and activity in organic tomato farming systems: Effects of organic inputs and straw mulching. Soil Biol. Biochem., 38: 247-255

Van Groenigen, K.J., Bloem, J., Baath, E., Boeckx, P., Rousk, J. and Bode, S. 2010. Abundance, production and stabilization of microbial biomass under conventional and reduced tillage. Soil Biol. Biochem. 42: 48-55. 


\section{How to cite this article:}

Vishalini, R., D. Rajakumar and Gomathy, M. 2019. Impact of Organic Mulches and Intercropping on Microbial Population and Enzyme Activities in Irrigated Finger Millet (Eleusine coracana L.). Int.J.Curr.Microbiol.App.Sci. 8(06): 298-305. doi: https://doi.org/10.20546/ijcmas.2019.806.034 